\title{
The Use of Apologies by EFL Learners
}

\author{
İlknur İstifçi \\ School of Foreign Languages, Anadolu University \\ Yunusemre kampusü \\ 26470 Eskisehir, TURKEY \\ Tel: 90-532-274-1133 E-mail: iistifci@gmail.com
}

\begin{abstract}
The aim of this study is to investigate the act of apologizing with subjects from two different levels of English proficiency to find out whether there are similarities and differences between these groups and whether they approach native speaker apology norms. 20 subjects in intermediate level, 20 subjects in advanced level and 5 native speakers of English participate in the study. The data are gathered by a Discourse Completion Test that had 8 apology situations. In the analysis of the data, all responses are categorized according to Cohen and Olshtain's (1981) apology speech act set. The results of the study reveal some similarities and differences between the two groups. Their L1 can be said to have an influence on their use of apologies, especially intermediate level subjects transfer native Turkish speaker norms into English.
\end{abstract}

Keywords: Communicative competence, Speech acts, Cross-cultural speech act studies, Discourse completion test, apologies

\section{Introduction}

Communicative competence has been the goal of teaching a second/foreign language and has gained importance in recent years since its introduction by Hymes in 1960s. As Hymes (1972) points out communicative competence involves not only rules of the language but also abstract knowledge about social and functional rules of language. For Hymes, knowledge of linguistic rules is supported by the competence of using the language appropriately in situations. As it is suggested in literature, while acquiring the language, native speakers of a language also acquire the knowledge of rules and choose among the speech acts when communicating with others. However, the situation is different when people learn a second/foreign language since speech acts have been accepted as one of the troublesome points in learning a second/foreign language (Wolfson 1989; Harlow 1990; Schmidt and Richards 1980). It has been claimed in literature that second/foreign language learners face problems in using speech acts as their usage requires sociopragmatic competence. Although speech acts are universal and can be found nearly in all languages, their usage differs according to the culture of the community. Cross-cultural studies of speech acts have shown that L2 learners face problems in using speech acts when they communicate with native speakers of the target language (Blum-Kulka and Olshtain 1984; Kasper 1990; Beebe et. al 1990; Koike 1989; Cohen and Olshtain 1993).

The speech act of apologies has also been investigated cross-culturally and some similarities and differences have been found between cultures in the use of apologies (Olshtain 1983; Garcia 1989; Suszczynska 1999; Cohen and Olshtain 1993; Blum-Kulka and Olshtain 1984). The studies mentioned above have been carried out in second language learning situations. The studies which have been carried out in EFL situation are the studies of Erçetin (1995) and Tunçel (1999). They have carried out studies on the use of apologies in a foreign language learning situation with EFL learners in Turkey and found out differences resulting from the culture of the learners.

The aim of this study is to investigate the act of apologizing with subjects from different levels of English proficiency in order to find out whether there are similarities and differences between their usage of apologies and whether they approach native speaker norms in using apologies.

The study tried to answer the following research questions:

1) What are the formulas used by intermediate and advanced level subjects in apology situations?

2) Are there any similarities and differences between their use of apologies?

3) Do they approach native speaker norms in using apologies?

\section{A Brief Review of Literature}

\subsection{Communicative Competence}

According to Richards et. al (1985) communicative competence includes knowledge of the grammar, vocabulary of the language, rules of speaking, knowing how to use and respond to different types of speech acts and knowing how to use 
language appropriately. Hymes has been accepted as a mentor in communicative competence approach and he views language behavior in terms if its appropriateness and correctness (İstifçi, 1998:12). Many researchers have agreed that communicative competence should be the goal of L2 teaching and communicative competence of learners should include the ability of how language is used in social contexts to perform communicative functions, and knowledge of how utterances and communicative functions can be combined according to the principles of discourse (Loveday 1982, Canale and Swain 1980).

Canale and Swain (ibid.) identified four components of communicative competence such as grammatical competence, discourse competence, sociolinguistic competence and strategic competence. Sociolinguistic competence includes appropriateness of meaning and appropriateness of form and for nonnative speakers every situation is potentially unfamiliar because of unknown sociolinguistic conventions (Shaw, 1992). Being a part of sociolinguistic competence, sociopragmatic competence in a language includes not only linguistic and lexical knowledge but also knowing how to vary speech act strategies according to the situational or social variables in communication (Harlow, 1990).

\subsection{Speech Acts}

Speech acts can be defined as the basic unit of communication and they are part of linguistic competence. As Schmidt and Richards (1980) state speech acts are all the acts we perform through speaking, all the things we do when we speak and the interpretation and negotiation of speech acts are dependent on the discourse or context. There are a series of analytic connections between the notion of speech acts, what the speaker means, what the sentence uttered means, what the speaker intends, what the hearer understands, and what the rules governing the linguistic elements are (Searle 1969; cited in Schiffrin 1994:54). Speech act theory has gained importance with Austin $(1975)$ and Searle $(1969,1976)$ who have made a distinction between what is actually said (locution), what is intended by what is said (illocution) and what is done by what is said (perlocution) (cited in İrman, 1996:39). According to Brown \& Levinson (1987) the locutionary aspect has to do with 'the utterance of a sentence with determinate sense and reference', the illocutionary aspect with 'the naming of a statement, offer, promise in uttering a sentence, by virtue of the conventional force associated with it', whereas the perlocutionary aspect deals with 'the bringing about of effects on the audience by means of uttering the sentence, such effects being special to the circumstances of utterance'. As research in this area suggests, the illocutionary force has been the concern of researchers who are interested in speech acts. Searle (1976) classifies speech acts with illocutionary aspect into some basic types such as representatives, directives, commissives, expressives and declarations.

Speech acts have also been classified as direct and indirect speech acts. According to Searle (ibid.) one speech act is brought about indirectly by performing another one in indirect speech acts and their interpretation changes according to the situation, the manner of speaking and to whom people speak. As Fraser (1978) claims indirect speech acts with illocutionary force are same across languages but their distribution, function and frequency of occurrence may show differences. According Blum-Kulka and Olshtain (1984) there are inter-cultural, cross-cultural and individual differences in using speech acts. Second language learners have been claimed to have disadvantages in using speech acts to communicate with native speakers of the target language because of the complexity of speech acts since they are conditioned by social, cultural, situational and personal factors (Cohen and Olshtain, 1993). Second language learners generally try to apply the rules they use in their first language when they speak in the second language. Thus, the result is communication breakdown or communication conflict.

\subsection{Interlanguage Pragmatics}

Interlanguage can be defined as the type of language produced by second and foreign language learners who are in the process of learning a language (Richards et. al, 1985). According to Ellis (1985) interlanguage is the systematic knowledge of language which is independent of both the learner's L1 and L2 system. Before 1970s, interlanguage studies were generally carried out to see grammatical development of L2 learners. However, by the emergence of communicative competence approach, interlanguage studies gave emphasis to the interactional and communicative dynamics of L2 performance. Thus, the term 'interlanguage pragmatics' came into existence. According to Kasper \& Blum-Kulka (1993) interlanguage pragmatics is the study of nonnative speakers' use and acquisition of linguistic action patterns in a second language and it places an emphasis on the pragmatic study that focuses on people's comprehension and production of linguistic action in context (Tunçel 1999:39). As Thomas (1983) states, L2 learners transfer L1 speech act rules into L2, so they engage in pragmalinguistic failure or their different perceptions about correct linguistic behavior cause sociopragmatic failure.

\section{4 Speech Act of Apologies}

The act of apologizing is called for when there is some behavior which has violated social norms. When an action or utterance has resulted in the fact that one or more persons perceive themselves as offended, the culpable person(s) needs to apologize. We are dealing here, therefore, with two parties: an apologizer and an apologizee. However, only if the 
person who caused the infraction perceive himself or herself as an apologizer do we get the act of apologizing. The act of apologizing requires an action or an utterance which is intended to "set things right" (Olshtain, 1983:235).

As Marquez-Reiter (2000: 44) states an apology is a "compensatory action for an offense committed by the speaker which has affected the hearer. According to Bataineh \& Bataineh (2006:1903) apologies fall under expressive speech acts in which speakers attempt to indicate their state or attitude. They add that in order for an apology to have an effect, it should reflect true feelings.

As Searle (1979) states a person who apologizes for doing A expresses regret at having done A so the apology act can take place only if the speaker believes that some act A has been performed prior to the time of speaking and that this act A resulted in an infraction which affected another person who is now deserving an apology (Olshtain, ibid., 235).

Apology speech acts have been investigated cross-culturally in order to find similarities and differences between the languages. The studies have generally been carried out in situations where learners learn the target language as their second language. The studies have shown that some learners employ language transfer from their L1, some learners approximate native speaker norms or some learners use completely different formulas different from the formulas they use in their L1 or L2.

Having carried out a study with 44 college subjects and comparing the use of apologies in Hebrew and English, Olshtain and Cohen (1993) found that native speakers' apology forms are patterned and nonnative speakers deviate from native speaker norms because of transfer and lack of proficiency.

Olshtain (1983) carried out a study with 63 college subjects (12 native English speakers, 12 native Hebrew subjects, 12 Russian subjects and 13 English speakers learning Hebrew at Teacher's College in Jerusalem) to compare their apology usage. According to the results obtained from his study, he claimed that English speakers' data differed from native Hebrew data and they employed transfer. He used the categorization of Cohen and Olshtain (1981) such as:

1) An expression of apology (Illocutionary Force Indicating Device IFID)

a) an expression of regret (e. g. I'm sorry)

b) an offer of apology (e.g. I apologize)

c) a request for forgiveness (e.g. excuse me, forgive me)

2) An offer of repair/redress (REPR) (e.g. I'll pay for your damage)

3) An explanation of an account (EXPL) (e.g. I missed the bus)

4) Acknowledging responsibility for the offense (RESP) (e.g. It's my fault)

5) A promise of forbearance (FORB) (e.g. I'll never forget it again)

Olshtain and Blum-Kulka (1985) carried out a study on requests and apologies with native speakers of Hebrew and learners of Hebrew. They found that the learners of Hebrew approached native speaker norms when they had the same rules in their native languages and deviated from native speakers when they had language-specific rules. They also found that nonnatives' length of stay in the target language community affected their choice of the formulas.

Erçetin (1995; cited in Tunçel 1999:49) carried out a study on the use of apologies by Turkish EFL learners and she claimed that EFL learners exhibited transfer from Turkish. Tunçel (1999) also carried out a study on the use of apologies and thanking with 129 EFL learners at Anadolu University, 50 native American and British speakers and 44 native Turkish speakers. His findings suggested that EFL learners exhibited transfer in the use of apologies from their L1 in some situations (e.g. the situation in which a driver dents the side of someone else's car or the situation in which a classmate does not return a book on time). He found that Turkish EFL learners tranferred some sociocultural norms of Turkish into English in above mentioned situations like blaming the driver or a friend instead of apologizing. He adds that transfer of the rules of $\mathrm{L} 1$ can cause misunderstandings and failure in communication.

\section{Methodology}

As it was stated in previous parts of this study, the use apologies was selected for this study because apology speech acts were found to reflect cultural values. It has also been suggested in literature that proficient learners use speech acts appropriately in communicating with native speakers of the target language. Thus, subjects of this study were 20 subjects from one of the intermediate level classes and 20 subjects in advanced level class. The data gathered from these subjects were used to find similarities and differences between the groups. In order to find native speaker norms, the data gathered from 5 native speakers of English. The data were collected using a Discourse Completion Test which had 8 apology situations.

\subsection{Subjects}

The subjects of this study were 20 intermediate level EFL learners, 20 advanced level EFL learners and 5 native speakers of English at Preparatory School of Anadolu University. The subjects in this school had taken the Michigan 
Placement Test at the beginning of the term and had been placed into different classes according to their proficiency levels. Subjects who scored between 46-60 were accepted as intermediate level subjects and subjects who scored between 76-100 were accepted as advanced level subjects. Although there were 7 intermediate classes at Preparatory School, one class of intermediate subjects and one class of advanced subjects served as the subjects of the study. Their ages ranged from $18-22$.

Native speakers of English are the teachers in Prep School. Their ages ranged from 26-37 and all of them have been in Turkey for more than two years. Although the number of native teachers was 5, it was thought that their answers to Discourse Completion Test could give an idea about native speaker usage of apologies.

\subsection{Discourse Completion Test}

The Discourse Completion Test (DCT) was taken from Tunçel (1999) and it had been adapted from other DCTs used in literature (Cohen and Olshtain 1981, Eisenstein and Bodman 1986, Tillett and Bruder 1985 and Bergman and Kasper 1993; cited in Tunçel 1999:57). The original version of the test consisted of 14 apology situations and they had been pilot tested before the actual study. The reliability of the test was $75 \%$. The test in this study consisted of 8 situations which were taken from Tunçel (ibid.) and they started with a description of the situation. The subjects were wanted to write the first thing that came into their minds. The situations in this study were organized according to the severity of the offense and social status of the apologizer and apologizee (see Appendix A for the discourse completion test).

EFL subjects were also given a short background questionnaire to have an idea about their age, sex and if they had been abroad. Native English speakers also completed the background questionnaire, they wrote about their country of origin, age, sex and the duration of their residence in Turkey.

\section{3 Data Collection Procedure}

DCT was applied to EFL subjects in their usual class hours by their usual core course teachers and they were instructed to write the first thing that came into their minds regarding the situation they were in and the person they were interacting. In the analysis of the data, all responses were categorized according to Cohen and Olshtain's (1981) apology speech act set. According to their categorization, there were 5 main categories such as the following:

1) An expression of apology (Illocutionary Force Indicating Device IFID)

a. an expression of regret (e. g. I'm sorry)

b. an offer of apology (e.g. I apologize)

c. a request for forgiveness (e.g. excuse me, forgive me)

2) An offer of repair/redress (REPR) (e.g. I'll pay for your damage)

3) An explanation of an account (EXPL) (e.g. My daughter was ill, I took her to hospital)

4) Acknowledging responsibility for the offense (RESP) (e.g. It's my fault)

5) A promise of forbearance (FORB) (e.g. I'll never forget it again)

As Tunçel (ibid.) states the above list did not cover all the responses of his subjects, so he added some other categories into the list such as:

6) Deny (denial of fault or offense) (e.g. I did not cause the accident. You parked your car on my way!)

7) Blame (putting blame on the hearer) (e.g. Why didn't you remind me?)

8) Health (asking the state of health) (e.g. Are you all right? I can take you to hospital)

9) Exclamation (EXL!) (expressing surprise) (e.g. Oh!)

10) Request (e.g. Can I use it for two days?)

The responses of 40 subjects and 5 native English speakers were counted and categorized according to the above criteria in the coding tables for each situation. The frequency and percentage of semantic formulas were calculated. In some situations, there were some combinations such as IFID+EXPL, REPR+RESP (see Appendix B for coding).

\section{Results}

As it was stated in the previous chapters, the aim of this study was to investigate the speech act realizations of EFL learners in situations which required apologies. The data were collected through a discourse completion test. The answers of the subjects were calculated and their frequencies were taken in order to make a comparison between the two groups.

\subsection{The Analysis of Situations}

As Table 1 reveals, the most common formula used by both intermediate and advanced level subjects was the use of IFID+EXPL (e.g. I'm sorry, by my daughter was ill; I'm sorry, I had to go to police station). This formula accounted for 
$60 \%$ of the data in both levels. Another common formula was EXPL (Explanation of an account) accounted for $25 \%$ for intermediate level subject data and $30 \%$ for advanced level subject data (e.g. My child was ill). Advanced level subjects used IFID+EXPL.+FORB 10\% (e.g: I'm extremely sorry, my car broke down, this won't happen again and intermediate level subjects used IFID + FORB formula 15\% (e.g: I'm sorry, I won't be late again). It's interesting to note that subjects in both levels did not use single IFID formula. When the native English speaker data is taken into account, it is seen that 3 subjects used IFID+EXPL, one subject used EXPL and one subject used a totally different category which did not exist in EFL data as IFID+REQUEST (e.g. I'm really sorry but I had an emergency at home. Would it be possible to reschedule for another time?). It is seen that IFID categories accounted for most of the data.

As table 2 reveals, advanced level subjects preferred IFID 5\% whereas intermediate level subjects did not prefer IFID. Explanation of an account (EXPL) was used by intermediate level subjects $45 \%$ while advanced level subjects used it $20 \%$ (e.g: I have to tidy my room, I couldn't get up).

A promise of forbearance (FORB) was employed by the subjects in both levels, $5 \%$ for intermediate level, $10 \%$ for advanced level. The percentage of EXPL+FORB was same for both groups, $5 \%$. IFID + EXPL preference of both groups was mostly used by intermediate level subjects (45\%) and advanced level subjects (40\%). Advanced level subjects differed from intermediate level subject in their use of IFID + EXPL + FORB (10\%), IFID + EXPL + RESP. $(5 \%)$ and IFID + RESP + FORB (5\%). Intermediate level subjects again did not prefer single IFID.

As for the native speakers of English, 3 subjects preferred IFID+EXPL and 2 subjects used a different category as IFID+EXPL+REQUEST (e.g. I'm sorry, I completely forgot that we were going to meet. Can we re-arrange a night out?).

Situation 3 was about a small car accident. As table 3 reveals, subjects in both groups employed a wide variety of strategies. In terms of IFID only 1 subject in intermediate level used it (5\%). The use of acknowledging responsibility (RESP) and IFID + FORB were same for both groups (5\%). 2 subjects in intermediate level preferred EXPL (10 \%), FORB (10 \%) and IFID + RESP (10\%). IFID + EXPL accounted for $15 \%$ for intermediate level and $5 \%$ for advanced groups. The subject in intermediate level employed BLAME (35\%). Combinations of IFID were used by advanced subjects. IFID + REPR (35\%), IFID + RESP+ REPR (20\%), IFID + RESP + FORB (5\%). IFID + RESP + REPR was used by 1 intermediate level subject. 2 advanced subjects preferred to use EXPL + REPR and 3 of them used RESP + REPR ( e.g. It's my fault, I'll pay your damage).

The use of BLAME can be said to be an influence from Turkish. 7 intermediate level subjects did not apology but put the blame on the other driver (e.g. That's your fault, shut up!. You parked in a wrong place).

Native English subjects, on the other hand, employed REPR ( 1 subject), IFID+EXPL (2 subjects), RESP+REPR (1 subject) and IFID+REPR (1 subject). It can be said that advanced level subjects employed the same categories as native speaker subjects.

Situation 4 was about forgetting the book of a classmate. As Table 4 shows, combinations of IFID were higher in both groups ( $40 \%$ for intermediate subjects, $60 \%$ for advanced subjects). Single IFID formulas were employed by only 2 subjects in advanced group. The use of REPR and IFID + EXPL + BLAME was same for both groups (5 \%). EXPL category was preferred only by 7 subjects in intermediate group. IFID + EXPL preference was higher in both groups ( $25 \%$ for intermediate, $20 \%$ for advanced group). 3 subjects in advanced group used IFID+EXPL + REPR (e.g. I'm sorry, I completely forgot about it, I'll bring it tomorrow). BLAME is used by 3 subjects in intermediate group (e.g. Why didn't you say?). Other formulas were used individually by the subjects in advanced group such as BLAME, IFID+BLAME, EXPL+FORB+BLAME + EXPL and IFID + RESP + REPR.

When the native English speaker data is taken into account, it is seen that 1 subject used RESP, 1 subject used IFID+EXPL+REPR and 3 subjects used IFID+EXPL. The use of the last category is similar to intermediate and advanced subjects' data. They can be said to approximate native English speaker norms.

Situation 5 was about bumping into an old lady accidentally. As Table 5 reveals IFID+EXP and IFID+RESP were the most commonly used categories by the subjects in intermediate level whereas IFID+RESP category was mostly used by the subjects in advanced level (e.g. Sorry, it was my fault). When all the data are taken into account, subjects in advanced level preferred to use a wide variety of strategies, 2 subjects preferred IFID+RESP+HEALTH, 3 subjects preferred IFID+HEALTH+REPR and 2 subjects preferred IFID+EXP+REPR (I'm sorry, I'm very careless. I'll help you pick up your packages).

There were also individual preferences in IFID, IFID+EXPL, IFID+HEALTH, REPR+HEALTH, IFID+RESP, IFID+RESP+REPR and IFID+RESP+REPR+HEALTH categories in advanced level data. 
Native English subjects mostly preferred IFID+HEALTH+REPR (3 subjects) category. 1 subject employed a totally new category such as EXL!+IFID+REPR (e.g. Oh, dear. I'm really sorry about that. Is there anything I can do for you?) (see Table 5).

Situation 6 was about accidentally breaking a vase of a friend. As Table 6 reveals, the subjects in intermediate and advanced levels differed in their use of formulas. BLAME, IFID+REPR $(20 \%)$ and IFID+EXPL+REPR (10\%) categories were mostly employed by the subjects in intermediate level whereas IFID+EXPL (25\%) and IFID+REPR $(40 \%)$ were commonly used by the subjects in advanced group. REPR and IFID+REPR+RESP categories were employed by 2 subjects in advanced group. In terms of the usage of IFID one subject per each group used it. The categories such as EXPL, FORB, IFID+EXPL, IFID+RESP, EXPL+REPR, IFID+REPR+RESP and $\mathrm{EXCL}+\mathrm{IFID}+\mathrm{REPR}$ were used by one subject in intermediate group. The use of IFID and combinations of IFID accounted for $70 \%$ of the data of intermediate group whereas it accounted for $30 \%$ of the data of advanced group.

In situation 7, intermediate level subjects preferred IFID (15\%) and IFID+EXP (45\%), BLAME (15\%) and IFID+HEALTH(15\%) mostly. Subjects in advanced group, on the other hand, preferred IFID+EXP (30\%), IFID+HEALTH (15\%) and IFID+EXPL+HEALTH (30\%). It's interesting to note that 3 subjects used BLAME and 1 subject preferred IFID+BLAME categories which were not preferred by the subjects in advanced group. This can be because of the effect of Turkish. Since the situation was about bumping a friend on the corner, 4 subjects in intermediate group put the blame on their friends such as "Why are you running so fast?"

The native English subjects in our study preferred IFID+HEALTH (2 subjects), BLAME (1 subject), IFID+EXPL+HEALTH (1 subject) and EXL!+IFID (1 subject). As the number of native English subjects are few, it is difficult to generalize the results. However, Tunçel's (1995) data can give some insights on native speaker usage. The data of his study revealed that native English speakers preferred IFID, IFID+EXPL, IFID+HEALTH, EXL!+IFID combinations. Our data reveals that the subjects in this study approached native speaker norms in using IFID+EXPL and IFID+HEALTH categories. The subjects in advanced group can be said to approach native speaker norms in terms of using EXL!+IFID+EXPL (5\%) and IFID+EXPL+HEALTH (30\%) categories.

As Table 8 demonstrates, REPR (10\%), EXPL (15\%), IFID+EXPL (20\%), IFID+REPR (15\%) and EXPL+REPR $(20 \%)$ were the categories which were commonly used by the subjects in intermediate group. The formulas used by the subjects in advanced group differed from those used by the subjects in intermediate group. They mostly preferred IFID and combinations of IFID. IFID+EXPL accounted for $10 \%$, IFID+REPR accounted for $15 \%$, EXPL+REPR $15 \%$ and EXL!+IFID+EXPL+REPR accounted for $20 \%$ of the data.

All native English subjects in this study preferred different strategies such as IFID+EXPL+REQUEST, IFID+EXPL, EXPL, EXL!+EXPL+REPR (e.g. Oh no, I knew I had forgotten something. I'll give you the book tomorrow) and Questioning + EXPL (e.g. I've been meaning to see you to return your book. Will you be in your office later?).

\section{Discussion}

The aim of this study was to compare and contrast the use of formulas of intermediate and advanced level subjects in situations which required apologies. The data revealed that the apology formulas of these two groups differed according to the situation. The formulas they mostly used were more or less similar in situations $1,2,4,5,6,7$ and 8 . There were also some individual differences in the data but they were not taken into consideration. In situations 1 and 2 they mostly employed EXPL and IFID+EXPL, in situation 4 they mostly chose IFID+EXPL, in situations 5 and 6 they mostly preferred IFID+REPR, in situation 7 they mostly chose IFID+EXPL and IFID+HEALTH formulas and in situation 8 their choice of IFID+REPR and EXPL+REPR were similar. In situation 3 the formulas they used differed. Subjects in intermediate level preferred to use EXPL, FORB, IFID+EXPL, IFID+RESP and BLAME mostly whereas subjects in advanced level used EXPL+REPR, RESP+REPR, IFID+REPR and IFID+RESP+REPR formulas. Intermediate subjects' use of BLAME in situations 3 and 4 can be explained as a transfer of sociocultural norm into English. This fact was proven to be true in Tunçel's study who pointed out that blaming is a typically Turkish norm where a driver bumped his car and expected to apologize, but put the blame on the other driver who was innocent. Although the formulas they used were similar in situation 4, subjects in intermediate and advanced groups employed other strategies. Intermediate level subjects preferred EXPL and BLAME category mostly whereas advanced level subjects used IFID, IFID+REPR and IFID+EXPL+REPR. These categories were similar to the categories of native English speakers in our data and in Tunçel's data. In situation 8 intermediate and advanced level subjects' use of formulas showed differences. Subjects in intermediate level preferred REPR, EXPL and IFID+EXPL mostly whereas advanced level subjects preferred IFID+EXPL, EXPL+REQUEST and IFID+EXPL+REPR+EXL!. Their use of EXL! category can be explained to approach target language norms because our data and the data of Tunçel revealed that exclamations are widely used by native English speakers.

In terms of IFID usage, advanced level subjects used this category and its combinations more than intermediate level subjects. IFID usage was also found to be prevalent among native English speakers and the overwhelming expression 
was "I'm sorry" which expresses regret (Holmes 1990). As Owen (1983; cited in Suszczynska 1999:1059) states the IFIDs are the strategies which are the most conventionalized and routinized, being as it were in the center of the speech act category of apologizing and representing verbal routines or syntactic-semantic formulae.

Although the main concern of this study was to compare and contrast intermediate and advanced level subjects' apology strategies, these data can be compared with our native English speaker data and native Turkish and English speaker data in Tunçel's study. Turkish speakers can be said to use apologies more differently than native English speakers. When native English speaker and native Turkish speaker data are taken into account, subjects in advanced level may be said to approach native English speaker norms. However, subjects in intermediate level may be said to employ Turkish norms in their target language usage. It is interesting to note that subjects in both levels, especially intermediate level subjects used some formulas which are not used in their target language in some situations. They developed their own interlanguage formulas.

\section{Conclusion}

The results of this study suggested that in some situations advanced level subjects approached native speaker norms more than the subjects in intermediate group in the use of apologies. However, in some situations it was seen that the formulas used by subjects in both groups were similar and different from native English data. Their L1 can be said to have an influence on their use of apologies, especially intermediate level subjects transferred native Turkish speaker norms into English such as blaming the other person. It is difficult to generalize the findings because the data were collected from $40 \mathrm{~L} 2$ learners. More reliable and valid conclusions might have been drawn had more subjects participated in the study.

The study showed that there are many instances in which L1 cultural norms affected the subjects' realization of apology speech acts. As Olshtain and Cohen (1983) suggest formal instruction on the use of speech acts by L2 learners speed up the process of learning the target language although acquisition of nativelike production by nonnative speakers may take many years. Teachers can develop students' metapragmatic ability by exposing them with real life situations through watching videos, role-playing and simulations, i. e. by engaging them in consciousness-raising tasks.

\section{References}

Bataineh, R. F. \& Bataineh, R. F. (2006). Apology strategies of Jordanian EFL university students. Journal of Pragmatics, 38, 1901-1927.

Blum-Kulka, S. \& Olshtain, E. (1984). "Requests and Apologies: A Cross-Cultural Study of Speech Act Realization Patterns (CCSARP)”. Applied Linguistics, 5 (1), 196-213.

Brown, P. \&. Levinson, S. C. (1987). Politeness: Some Universals in Language Usage. Cambridge: CUP.

Canale M. \& Swain, M. (1980). "From Communicative Competence to Communicative Language Pedagogy". In Richards, J. \& Schmidt, R. (Eds.) Language and Communication. London: Longman.

Cohen, D. A. \&. Olshtain, E. (1981). "Developing a Measure of Sociocultural Competence: The Case of Apology". Language Learning. 31 (1), 113-134.

Cohen, D. A. \& Olshtain, E. (1993). "The Production of Speech Acts by EFL Learners". TESOL Quarterly. 27 (1), $33-55$.

Ellis, R. (1985). Understanding Second Language Acquisition. Oxford: OUP.

Erçetin, N. G. (1995). "Pragmatic Transfer in the Realization of Apologies: The Case of Turkish EFL Learners". An unpublished M.A. Thesis. İstanbul: Boğaziçi Üniversitesi.

Fraser, B. (1981). “On Apologizing”. In Coulmas, F. (ed.) Conversational Routine. Mouton: The Hague.

Garcia, C. (1989). "Apologizing in English: Politeness strategies used by native and non-native speakers". Multilingua, $8(1), 3-20$.

Harlow, L. (1990). "Do they mean what they say? Sociopragmatic Competence and Second Language Learners". The Modern Language Journal, 74 (3).

Hymes, D. (1972). “On Communicative Competence”. In J. B. Pride and J. Holmes (Eds.). London: Penguin Books Ltd.

İrman, İ. (1996). "An Evaluation of the Communicative Success of Turkish EFL Learners in Utilizing Politeness Strategies in Requests". An unpublished M.A. Thesis. Eskişehir: Anadolu Üniversitesi. SBE.

İstifçi, İ. (1998). “An Interlanguage Study of Compliment Responses: A Case of Turkish Learners of English”. An unpublished M.A. Thesis. Eskişehir: Anadolu University. SBE. 
Kasper, G. \& Blum-Kulka, S. (1993). “Interlanguage Pragmatics: an Introduction”. In Kasper, G. \& Blum-Kulka, S. (Eds.) Interlanguage Pragmatics. Oxford. OUP.

Loveday, L. (1982). The Sociolinguistics of Learning and Using a Nonnative Language. Oxford: Pergamon Press.

Marquez-Reiter, R. (2000). Linguistic politeness in Britain and Uruguay: a contrastive study of requests and apologies. Amsterdam: John Benjamins Publishing Company.

Olstain, E. (1983) "Sociocultural Competence and Language Transfer: The Case of Apology". In Gass, S. L. Selinker (Eds.) Language Transfer in Language Learning. Rowley: Newbury House Publishers.

Richards, J. C., J. Platt and H. Weber (1985). Longman Dictionary of Applied Linguistics. Longman: England.

Schmidt, R. W. \& Richards, J. C. (1980). “Speech Acts and Second Language Learning”. Applied Linguistics, 1 (2), 129-157.

Schriffin, D. (1994). Approaches to Discourse. Cambridge: Blackwell Publishers.

Searle, J. (1976). “The Classification of Illocutionary Acts”. Language in Society, 5 (1), 1-24.

Suszczynska, M. (1999). "Apologizing in English, Polish and Hungarian: Different languages, different strategies". Journal of Pragmatics, 31, 1053-1065.

Thomas, J. (1983). “Cross-Cultural Pragmatic Failure”. Applied Linguistics, 4 (2), 91-112.

Tunçel, R. (1999) "Speech Act Realizations of Turkish EFL Learners: A Study on Apologizing and Thanking”. Unpublished PhD Dissertation. Eskişehir: Anadolu Üniversitesi. SBE.

Wolfson, N. (1989). Perspectives: Sociolinguistics and TESOL. Mass.: N. H. Pub. Inc.

\section{Appendix A}

\section{Discourse Completion Test}

1. You completely forget a crucial meeting at the office with your boss. An hour later you call him to apologize. The problem is that this is the second time you've forgotten such a meeting. Your boss gets on the line and asks: Boss : "What happened to you?"

2. You forget a get-together with a friend. You call him to apologize. This is really the second time you've forgotten such a meeting. Your friend asks over the telephone:

Friend:" What happened?"

3. Backing out of a parking place, you run into the side of another car. It was clearly your fault. You dent in the side door slightly. The driver gets out and comes over to you angrily.

Driver: "Can't you look where you're going? See what you've done!"

You:

4. You promised to return a textbook to your classmate within a day or two, after xeroxing a chapter. You held onto it for almost two weeks.

Classmate : I'm really upset about the book because I needed it to prepare for last week's class.

You:

5. You accidentally bump into a well-dressed elderly lady at an elegant department store, causing her to spill her packages all over the floor. You hurt her leg, too. It's clearly your fault and you want to apologize profusely.

You:

6. Spending an evening at a friend's apartment, you accidentally break a small vase belonging to her.

You:

7. Rushing to get to class on time, you run round the corner and bump into one of your fellow students who were waiting there, almost knocking him down.

You:

8. You have forgotten to return the book you borrowed from your professor. On the staff corridor you come across your professor.

You: 


\section{Appendix B}

\section{Coding Scheme of Apologies}

IFID: Illocutionary Force Indicating Device which includes apology speech acts such as "I'm sorry", "Excuse me", "Forgive me", "I'm terribly sorry".

REPR: an offer of repair or redress or compensation for the damage (e.g. I'll pay for your damage, I'll buy you another one).

EXPL: giving explanation, cause or reason (e.g. I took my daughter to hospital, I completely forgot about meeting).

RESP: acknowledging responsibility for the offense (e.g. It was my fault, What an absent-minded person I am!).

FORB: promising for not repeating the action again (e.g. I'll never forget to meet you again).

BLAME: putting the blame on the other person (e.g. Why didn't you remind me?, You parked your car in the middle of the road!).

HEALTH: after an undesired behavior asking the health of the person (e.g. Are you all right? I can take you to hospital).

REQUEST: asking for something politely (e.g. Could you give me the book for a few days?).

EXL!: using words that show surprise (e.g. Oh!, Oops!).

QUESTIONING: asking a question (e.g. Is it possible to use the book for two days?).

Table 1. Frequency of the use of semantic formulas in situation 1.

\begin{tabular}{|l|c|c|c|c|}
\hline \multirow{2}{*}{ Formulas } & \multicolumn{2}{|c|}{ Intermediate Level Subjects } & \multicolumn{2}{c|}{ Advanced Level Subjects } \\
\cline { 2 - 5 } & $\mathrm{N}$ & $\%$ & $\mathrm{~N}$ & $\%$ \\
\hline IFID & 0 & 0 & 0 & 0 \\
\hline REPR & 0 & 0 & 0 & 0 \\
\hline EXPL & 5 & 25 & 6 & 30 \\
\hline RESP & 0 & 0 & 0 & 0 \\
\hline FORB & 0 & 0 & 0 & 0 \\
\hline IFID + EXP & 12 & 60 & 12 & 60 \\
\hline IFID + EXP + FORB & 0 & 0 & 2 & 10 \\
\hline IFID + FORB & 3 & 15 & 0 & 0 \\
\hline TOTAL & 20 & 100 & 20 & 100 \\
\hline
\end{tabular}

Table 2. Frequency of the use of semantic formulas in situation 2 .

\begin{tabular}{|l|c|c|c|c|}
\hline \multirow{2}{*}{\multicolumn{2}{c|}{ Formulas }} & \multicolumn{2}{|c|}{ Intermediate Level Subjects } & \multicolumn{2}{c|}{ Advanced Level Subjects } \\
\cline { 2 - 5 } & $\mathrm{N}$ & $\%$ & $\mathrm{n}$ & $\%$ \\
\hline IFID & 0 & 0 & 1 & 5 \\
\hline REPR & 0 & 0 & 0 & 0 \\
\hline EXPL & 9 & 45 & 4 & 20 \\
\hline RESP & 0 & 0 & 0 & 0 \\
\hline FORB & 1 & 5 & 2 & 10 \\
\hline EXPL + FORB & 1 & 5 & 1 & 5 \\
\hline IFID + EXP + FORB & 0 & 0 & 2 & 10 \\
\hline IFID + EXPL + RESP & 0 & 0 & 1 & 5 \\
\hline IFID + RESP + FORB & 0 & 0 & 1 & 5 \\
\hline IFID + EXPL. & 9 & 45 & 8 & 40 \\
\hline TOTAL & 20 & 100 & 20 & 100 \\
\hline
\end{tabular}


Table 3. Frequency of the use of semantic formulas in situation 3 .

\begin{tabular}{|l|c|c|c|c|}
\hline \multirow{2}{*}{\multicolumn{2}{c|}{ Formulas }} & \multicolumn{2}{|c|}{ Intermediate Level Subjects } & \multicolumn{2}{c|}{ Advanced Level Subjects } \\
\cline { 2 - 5 } & $\mathrm{N}$ & $\%$ & $\mathrm{n}$ & $\%$ \\
\hline IFID & 1 & 5 & 0 & 0 \\
\hline REPR & 1 & 5 & 1 & 5 \\
\hline EXPL & 2 & 10 & 0 & 0 \\
\hline RESP & 0 & 0 & 0 & 0 \\
\hline FORB & 2 & 10 & 0 & 0 \\
\hline IFID + EXPL & 3 & 15 & 1 & 5 \\
\hline EXPL + FORB & 1 & 5 & 1 & 5 \\
\hline IFID + RESP & 2 & 10 & 0 & 0 \\
\hline BLAME & 7 & 35 & 0 & 0 \\
\hline EXPL + REPR & 0 & 0 & 2 & 10 \\
\hline IFID + RESP + FORB & 0 & 0 & 1 & 5 \\
\hline RESP.+ REPR. & 0 & 0 & 3 & 15 \\
\hline IFID + REPR. & 0 & 0 & 7 & 35 \\
\hline IFID + RESP. + REPR. & 1 & 5 & 4 & 20 \\
\hline TOTAL & 20 & 100 & 20 & 100 \\
\hline
\end{tabular}

Table 4. Frequency of the use of semantic formulas in situation 4.

\begin{tabular}{|l|c|c|c|c|}
\hline \multicolumn{1}{|c|}{ Formulas } & \multicolumn{2}{c|}{ Intermediate Level Subjects } & \multicolumn{2}{c|}{ Advanced Level Subjects } \\
\hline & $\mathrm{N}$ & $\%$ & $\mathrm{n}$ & $\%$ \\
\hline IFID & 0 & 0 & 2 & 10 \\
\hline REPR & 1 & 5 & 1 & 5 \\
\hline EXPL & 7 & 35 & 0 & 0 \\
\hline RESP & 0 & 0 & 1 & 5 \\
\hline FORB & 0 & 0 & 0 & 0 \\
\hline IFID + EXPL & 5 & 25 & 4 & 20 \\
\hline IFID + REPR. & 1 & 5 & 2 & 10 \\
\hline BLAME & 3 & 15 & 1 & 5 \\
\hline IFID + BLAME & 0 & 0 & 1 & 5 \\
\hline EXPL + FORB & 0 & 0 & 1 & 5 \\
\hline BLAME + EXPL.. & 0 & 0 & 1 & 5 \\
\hline IFID + EXPL + BLAME & 1 & 5 & 1 & 5 \\
\hline IFID + EXPL + REPR & 0 & 0 & 3 & 15 \\
\hline IFID + REPR + RESP & 0 & 0 & 1 & 5 \\
\hline EXCL + REPR & 1 & 5 & 0 & 0 \\
\hline IFID + RESP. & 1 & 5 & 0 & 0 \\
\hline EMPTY & 0 & 0 & 1 & 5 \\
\hline TOTAL & 20 & 100 & 20 & 100 \\
\hline
\end{tabular}

Table 5. Frequency of the use of semantic formulas in situation 5.

\begin{tabular}{|l|c|c|c|c|}
\hline \multicolumn{1}{|c|}{ Formulas } & \multicolumn{2}{|c|}{ Intermediate Level Subjects } & \multicolumn{2}{c|}{ Advanced Level Subjects } \\
\hline \multicolumn{1}{|c|}{} & $\mathrm{N}$ & $\%$ & $\mathrm{n}$ & $\%$ \\
\hline IFID & 1 & 5 & 1 & 5 \\
\hline REPR & 1 & 5 & 0 & 0 \\
\hline EXPL & 0 & 0 & 0 & 0 \\
\hline RESP & 0 & 0 & 0 & 0 \\
\hline FORB & 0 & 0 & 0 & 5 \\
\hline IFID + EXPL & 6 & 30 & 1 & 5 \\
\hline IFID + HEALTH & 0 & 0 & 1 & 5 \\
\hline REPR+HEALTH & 0 & 0 & 1 & 0 \\
\hline RESP+HEALTH & 1 & 5 & 0 & 5 \\
\hline IFID+RESP & 2 & 10 & 1 & 30 \\
\hline IFID+REPR & 6 & 30 & 6 & 10 \\
\hline IFID+RESP+HEALTH & 0 & 0 & 2 & 5 \\
\hline IFID + RESP+REPR & 0 & 0 & 1 & 15 \\
\hline IFID + HEALTH + RESP & 1 & 5 & 3 & 10 \\
\hline IFID + EXPL+RESP. & 1 & 5 & 2 & 5 \\
\hline IFID+RESP+REPR+HEALTH & 0 & 0 & 1 & 0 \\
\hline EMPTY & 1 & 5 & 0 & 100 \\
\hline TOTAL & 20 & 100 & 20 & \\
\hline
\end{tabular}


Table 6. Frequency of the use of semantic formulas in situation 6 .

\begin{tabular}{|l|c|c|c|c|}
\hline \multicolumn{1}{|c|}{ Formulas } & \multicolumn{2}{|c|}{ Intermediate Level Subjects } & \multicolumn{2}{c|}{ Advanced Level Subjects } \\
\hline & $\mathrm{N}$ & $\%$ & $\mathrm{n}$ & $\%$ \\
\hline IFID & 1 & 5 & 1 & 5 \\
\hline REPR & 2 & 10 & 2 & 10 \\
\hline EXPL & 1 & 5 & 0 & 0 \\
\hline RESP & 0 & 0 & 0 & 0 \\
\hline FORB & 1 & 5 & 0 & 0 \\
\hline IFID + EXPL & 1 & 5 & 5 & 0 \\
\hline BLAME & 3 & 15 & 0 & 40 \\
\hline IFID+REPR & 4 & 20 & 8 & 0 \\
\hline IFID+RESP & 1 & 5 & 0 & 0 \\
\hline EXPL+REPR & 1 & 5 & 0 & 5 \\
\hline IFID+EXPL+RESP & 3 & 15 & 1 & 10 \\
\hline IFID + REPR+RESP & 1 & 5 & 2 & 5 \\
\hline IFID + REPR+FORB & 0 & 0 & 1 & 0 \\
\hline EXCL+IFID+REPR & 1 & 5 & 0 & 100 \\
\hline TOTAL & 20 & 100 & 20 & \\
\hline
\end{tabular}

Table 7. Frequency of the use of semantic formulas in situation 7.

\begin{tabular}{|l|c|c|c|c|}
\hline \multirow{2}{*}{ Formulas } & \multicolumn{2}{|c|}{ Intermediate Level Subjects } & \multicolumn{2}{c|}{ Advanced Level Subjects } \\
\hline \multicolumn{1}{|c|}{} & $\mathrm{N}$ & $\%$ & $\mathrm{n}$ & $\%$ \\
\hline IFID & 3 & 15 & 1 & 5 \\
\hline REPR & 0 & 0 & 0 & 0 \\
\hline EXPL & 0 & 0 & 1 & 5 \\
\hline RESP & 0 & 0 & 0 & 0 \\
\hline FORB & 0 & 0 & 0 & 0 \\
\hline IFID + EXPL & 9 & 45 & 6 & 30 \\
\hline BLAME & 3 & 15 & 0 & 0 \\
\hline IFID+BLAME & 1 & 5 & 0 & 0 \\
\hline IFID+HEALTH & 3 & 15 & 3 & 15 \\
\hline HEALTH+EXPL & 1 & 5 & 0 & 0 \\
\hline EXL!+IFID+EXPL & 0 & 0 & 1 & 5 \\
\hline IFID + EXPL+HEALTH & 0 & 0 & 6 & 30 \\
\hline EMPTY & 0 & 0 & 2 & 10 \\
\hline TOTAL & 20 & 100 & 20 & 100 \\
\hline
\end{tabular}

Table 8 . Frequency of the use of semantic formulas in situation 8 .

\begin{tabular}{|l|c|c|c|c|}
\hline & \multicolumn{2}{|c|}{ Intermediate Level Subjects } & \multicolumn{2}{c|}{ Advanced Level Subjects } \\
\hline \multicolumn{1}{|c|}{ Formulas } & $\mathrm{N}$ & $\%$ & $\mathrm{~N}$ & $\%$ \\
\hline IFID & 0 & 0 & 1 & 5 \\
\hline REPR & 2 & 10 & 0 & 0 \\
\hline EXPL & 3 & 15 & 1 & 5 \\
\hline RESP & 0 & 0 & 0 & 0 \\
\hline FORB & 0 & 0 & 0 & 0 \\
\hline IFID + EXPL & 4 & 20 & 2 & 10 \\
\hline BLAME & 0 & 0 & 1 & 5 \\
\hline IFID+REPR & 3 & 15 & 3 & 15 \\
\hline EXPL+REPR & 4 & 20 & 3 & 15 \\
\hline REQUEST & 1 & 5 & 0 & 0 \\
\hline EXPL+REQUEST & 0 & 0 & 2 & 10 \\
\hline IFID + EXPL+REQUEST & 0 & 0 & 1 & 5 \\
\hline IFID + RESP+REPR & 1 & 5 & 1 & 5 \\
\hline IFID + EXPL+REPR+EXL! & 0 & 0 & 4 & 20 \\
\hline QUESTIONING & 1 & 5 & 0 & 0 \\
\hline EMPTY & 1 & 5 & 1 & 5 \\
\hline TOTAL & 20 & 100 & 20 & 100 \\
\hline
\end{tabular}

